\title{
The Art of Charcot: An Outstanding Caricaturist
}

\author{
Hélio A.G. Teive ${ }^{a, b}$ Gustavo L. Franklin ${ }^{a}$ Plínio Lima ${ }^{a}$ \\ Francisco M.B. Germiniani $^{a}$ Carlos Henrique F. Camargo ${ }^{b}$ \\ Olivier Walusinskic
}

${ }^{a}$ Neurology Service, Internal Medicine Department, Hospital de Clínicas, Federal University of Paraná, Curitiba, Brazil; ${ }^{b}$ Neurological Diseases Group, Postgraduate Program in Internal Medicine, Internal Medicine Department, Hospital de Clínicas, Federal University of Paraná, Curitiba, Brazil; 'Private Clinic, Brou, France

\section{Keywords}

Neurology $\cdot$ History $\cdot$ Arts $\cdot$ Humor $\cdot$ Caricatures

\begin{abstract}
Jean-Martin Charcot is considered the father of modern neurology; alongside his work as a physician, professor, and researcher in this area, he was also artistically gifted with a taste for caricature. This historical note summarizes 8 caricatures by Charcot that exhibit a mixture of humor, satire, irony, and sarcasm.

(c) 2021 S. Karger AG, Basel
\end{abstract}

\section{Introduction}

Jean-Martin Charcot (1825-1893) is considered the father of modern neurology as well as the 19th century's most important professor of this subject $[1,2]$. In addition to his numerous scientific contributions to neurology in general, Charcot's research also involved neuropathology, neuropsychiatry, and neuropsychology [15]. Alongside his scientific activities, Charcot had a great appreciation for the arts and significant artistic skills [3-

karger@karger.com www.karger.com/ene

Karger"
9]. He was also known to have a secret, complex personality and a taciturn profile with elements of authoritarianism, tyranny, austerity, ambition, sarcasm, and skepticism [3-6].

We selected 8 of Charcot's caricatures (Fig. 1-6) [7, 9, 10]. These images represent different stages of Charcot's life, drawn during his youth (1842), his tenure as a professor of medicine, and even into his old age (around 1870). This historical note discusses Charcot's artistic side through his caricatures.

Like Charcot, a number of neuroscientists were also skilled artists and draftsmen: these include Charles Bell (1774-1842), Pierre Samuel Toussaint FromentinDupeux (1786-1867), Frédéric Estre (1813-1902), Paul Richer (1849-1933), and the brothers Santiago (18521934) and Pedro Ramón y Cajal (1854-1950) [11-14]. The Cajals and Bell used these skills to illustrate their work [11-14]. Bell combined his varied artistic and scientific talents in detailed anatomical and surgical illustrations and paintings in several books. These include his 1811 text, An Idea of a New Anatomy of the Brain, as well as the first textbook on the anatomy and physiology of facial expression, entitled Essays on the Anatomy of Expression in Painting (1806) [12, 13]. Santiago Ramón y 


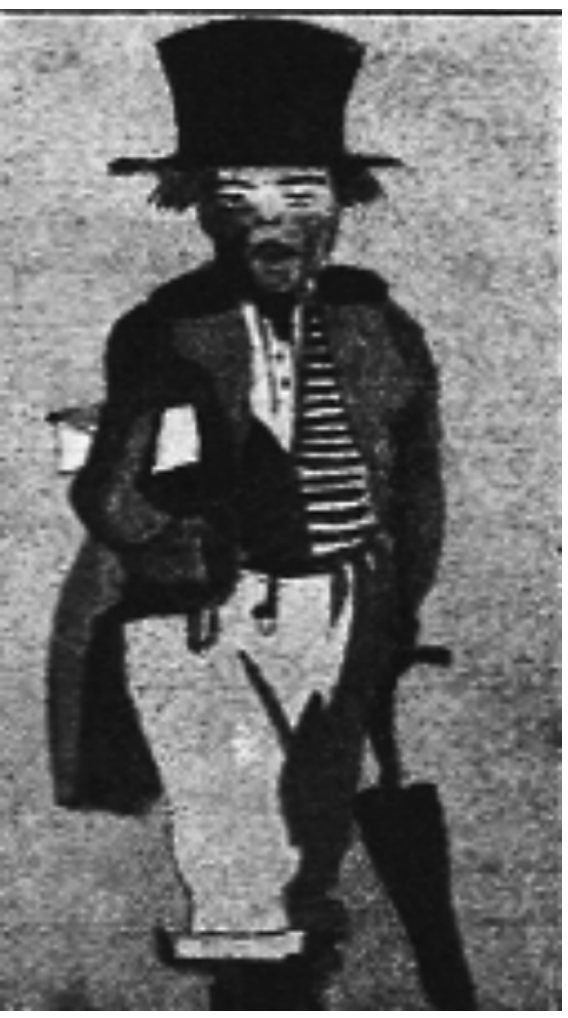

Fig. 1. Young student in the Quartier Latin. From the collection of Olivier Walusinski.

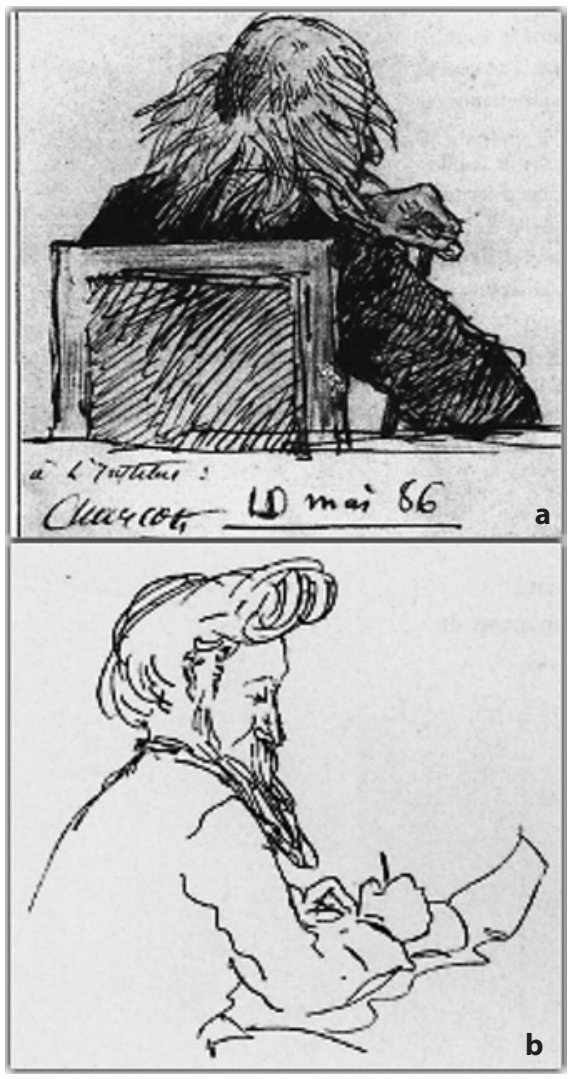

Fig. 2. Professors: Professor Chevreul (a) and Professor Pierret (b). From the collection of Olivier Walusinski.

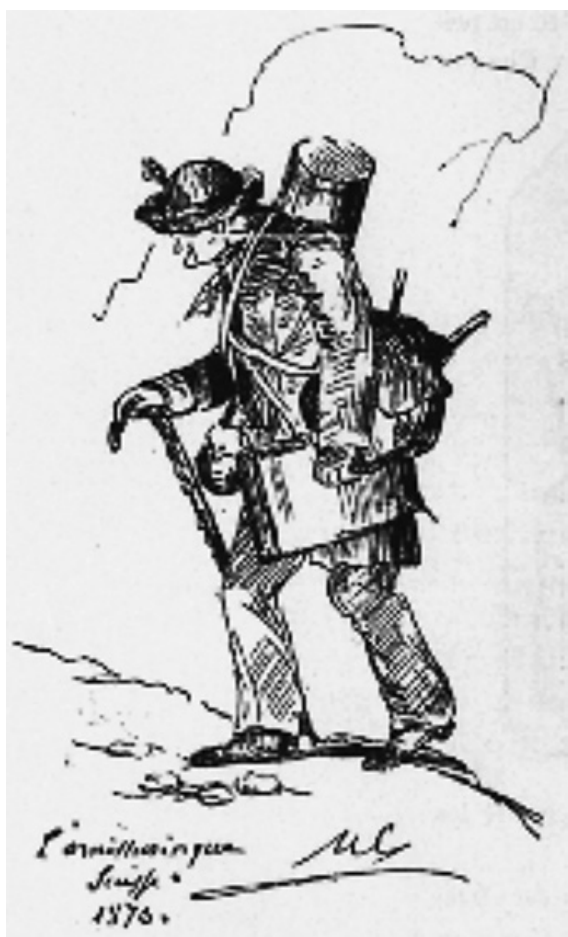

Fig. 3. Platypus. From the collection of Olivier Walusinski.

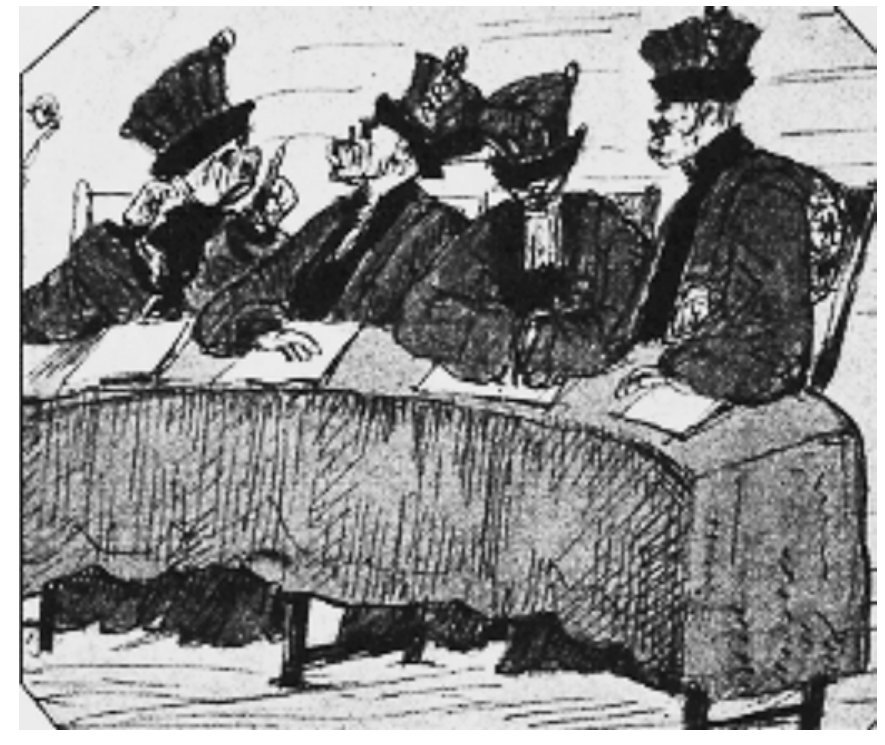

Fig. 4. The Aeropagus. From the collection of Olivier Walusinski.
Cajal drew and studied histological slides of the nervous system in great detail; in 1891, he proposed the law of dynamic polarization, establishing that the information flow within each neuron generally moves from the dendrites toward the axon [14]. Pedro provided Santiago with all his histological preparations and made a number of his own drawings from his histological findings [11]. Henry Tonks (1862-1937), a British surgeon, used his impressive drawing ability more like Charcot, with caricatures $[12,13]$. However, while Tonks dedicated more time to this area and studied in the evenings at the Westminster School of Art, Charcot was always self-taught. The young Jean-Martin had already shown specific artistic abilities. His father had suggested that his son should become an artistic painter $[7,8,12,13]$.

Charcot's caricatures express his characteristic style mixing humor, irony, satire, and sarcasm [15]. Our first example (Fig. 1) was drawn when Charcot visited the Latin Quarter of Paris at age 17 years and depicts a bohemian student, probably inspired by Charcot's encounters 
Fig. 5. Faculty procession. From the collection of Olivier Walusinski.

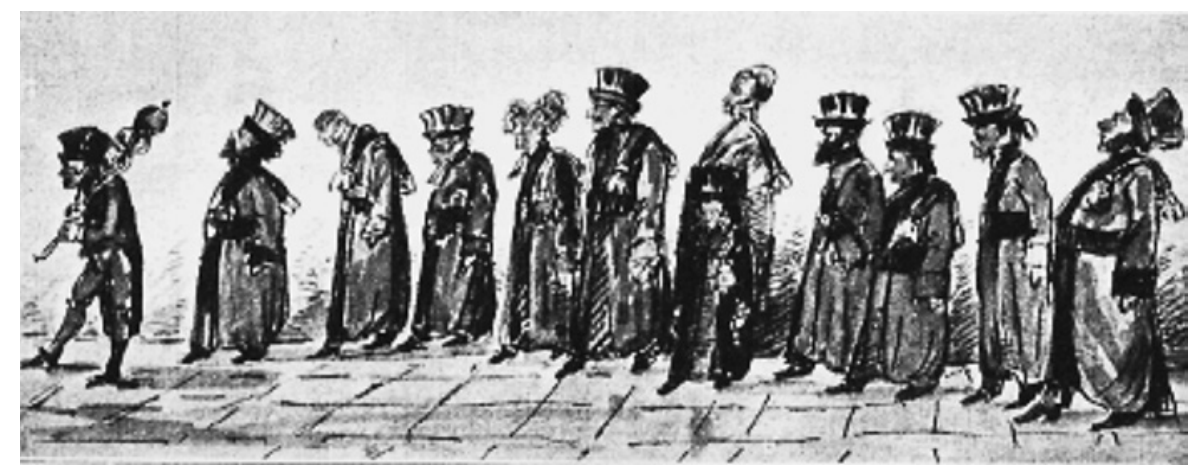

with what Meige describes as the type of student immortalized by caricaturists of that era [7].

The second drawing (Fig. 2a) represents Professor Michel Eugene Chevreul (1786-1889) during his visit to a Tuesday session at the Academy of Sciences in Paris around 1885 [7]. Charcot was seated behind him, and his caricature highlights the scholar's halo-like hair; the cartoon was instantly recognizable to anyone who knew the old professor, who by this time was approximately 99 years old [7]. Charcot also drew his own students, as seen in Figure 2b. This image depicts a hairy, bearded man concentrating on his work. This was Antoine-Auguste Pierret (1845-1920): first Charcot's student, then one of his first collaborators, and a traveling companion and friend who himself became a professor himself [7]. The sketch features an enormous forehead, a disproportional nose, and a matching chin [7]. Another caricature by Charcot is more humorous (Fig. 3) and depicts an old companion from his youth nicknamed "Platypus," on an excursion in the mountains of Switzerland while heavily loaded with tools, saddlebags, boxes, and cartons like a mule [7].

Charcot famously professed a singular disregard for all human antics but demonstrated tenderness toward and extreme indulgence of animals, particularly dogs and monkeys $[7,16,17]$. According to his biographers, Charcot furiously opposed hunters but tolerated all the fantasies of a $\operatorname{dog}[7,16,17]$. Following the example of the Flemish Baroque painter David Téniers, whose satires depicted busy monkeys doing the work of men, Charcot portrayed his own colleagues at the medical school in Paris in a similar and sharply ironic manner [7]. At the time that he drew the Areopagus comprising apes, Charcot was already on the faculty (Fig. 4) [7]. Next was another ironic caricature of his colleagues at the Paris medical school in pompous costumes during a procession, which he also entitled "Areopagus" (Fig. 5). The leader is bent
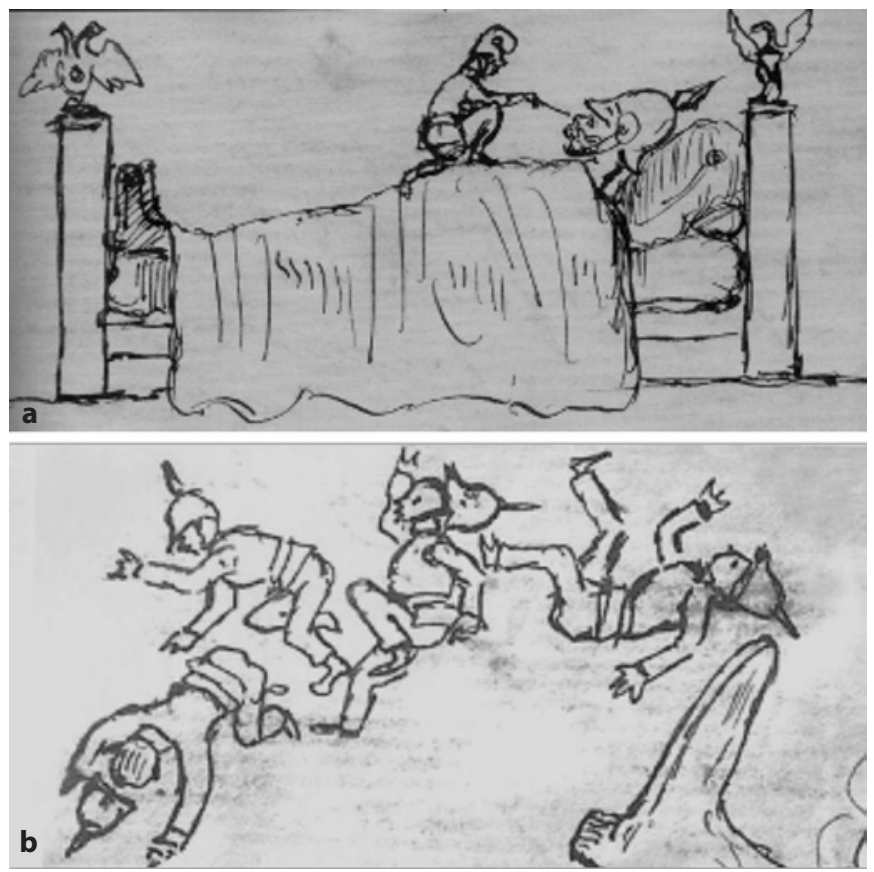

Fig. 6. Franco-Prussian War. a The great inert Prussian soldier. b L'Avenir (The Future). From the collection of Olivier Walusinski (a); reference [11] (b).

under the weight of his heavy silver caduceus staff and is followed by a parade of professors: tall and short, fat and thin, bald and shaved, hairy and bearded, some with glasses and some without, and some with heads held high and others with their noses practically in their gowns, in the words of Meige [7]. One figure depicts Charcot himself. The final 2 images portray his indignation during the Franco-Prussian war (1870); the first is untitled (Fig. 6a), depicting a tiny French soldier atop an enormous, inert Prussian one, and the second he called "L'Avenir" ("The Future," Fig. 6b) [10, 18]. 


\section{Conclusion}

This historical note briefly describes 8 caricatures drawn by Jean-Martin Charcot during the second half of the 19th century in Paris, demonstrating his artistic gifts that blend humor, satire, irony, and sarcasm.

\section{Statement of Ethics}

We confirm that approval of an institutional review board was not required for this work. We confirm that we have read the Journal's position on issues involved in ethical publication and affirm that this work is consistent with those guidelines.

\section{Conflict of Interest Statement}

There is no conflict of interest to declare.

\section{Funding Sources}

No targeted funding reported.

\section{Author Contributions}

1. Project: A. conception, B. organization, and C. execution;

2. Manuscript: A. writing of the first draft, and B. review and critique.

Hélio Teive, MD, PhD: 1A, 1B, 1C, and 2A. Gustavo L. Franklin, MD, PhD: 1C, and 2A. Plínio Lima, MD: 1C and 2A. Francisco M.B. Germiniani, MD: $1 \mathrm{C}$ and 2A. Carlos Henrique Ferreira Camargo, $\mathrm{MD}, \mathrm{PhD}: 1 \mathrm{C}$ and 2B. Olivier Walusinski, $\mathrm{MD}$ : $1 \mathrm{C}$ and 2B.

\section{References}

1 Guillain G. JM Charcot: his life-his work. New York: Paul B. Heber; 1959. p. 16-29.

2 Goetz CG, Bonduelle M, Gelfand T. Charcot: constructing neurology. New York: Oxford University Press; 1995. p. 268-304.

3 Guinon G. Charcot intime. Paris Medical; 1925 Mai 23. p. 511-6.

4 Souques A. Charcot intime. La Presse Medicale; 1925 Mai 27. p. 693-8.

5 Bonduelle M. [The intimate charcot]. Rev Neurol. 1994;150(8-9):524-8.

6 Poirier J. Jean-Martin Charcot (1825-1893): sa personne, sa personnalité, son personnage. Neurol Lib. 2013;3(Jul-Sep).

7 Meige H. Charcot artiste. Paris, France: Masson ET Cie; 1925
8 Bogousslavsky J. Charcot and art: from a hobby to science. Eur Neurol. 2004;51(2):78-83.

9 Charcot JM, Richer P. In: Delahaye A, Lecrosnier $\mathrm{E}$, editors. Les démoniaques dans l'art. Paris, France; 1887.

10 Bouchara C. Charcot. Une vie avec l'image. Paris, France: Philippe Rey; 2013.

11 de Castro F. Cajal and the Spanish Neurological School: neuroscience would have been a different story without them. Front Cell Neurosci. 2019 May 24;13:187.

12 Weiner MF, Russell Silver J. The doctor as an artist. J Med Biogr. 2017 May;25(2):80-90.

13 Ohry A. Physicians as painters. Isr Med Assoc J. 2003;5(9):681-4.

14 Ramón Y, Cajal S, de Carlos JA. Pedro Ramón y Cajal: the legacy of a neurohistologist, a medical doctor, and a pathologist. Anat Rec. 2020 May;303(5):1189-202.
15 Teive HAG, Germiniani FMB, Munhoz RP. Charcot's irony and sarcasm. Arq Neuropsiquiatr. 2017;75(6):402-4.

16 Moraes e Silva M, Meira AT, Walusinski O, Camargo CHF, Teive HAG. Charcot's paradox. Arq Neuropsiquiatr. 2019;77(8):590-3.

17 Nascimento FA, Camargo CHF, Walusinski $\mathrm{O}$, Teive HAG. Charcot and his passion for dogs: a historical note. Eur Neurol. $2020 \mathrm{Nov}$ $11 ; 1-3$.

18 Teive HAG, Tensini F, Germiniani FMB, Camargo CHF, Walusinski O. The melted statue of Charcot: the Nazi occupation of Paris during World War II. Eur Neurol. 2019;81(3-4): $182-7$. 